\title{
Kewatek, the Ikat Textiles from Adonara
}

\section{Social, Cultural, and Economic Changes}

\author{
Petronela Somi Kedan | ORCID: 0000-0003-1825-3500 \\ Wageningen University, Wageningen, The Netherlands \\ nela_somi@yahoo.com \\ Leontine Visser | ORCID: 0000-002-9180-8608 \\ Wageningen University, Wageningen, The Netherlands \\ voorhoevisserle@gmail.com
}

\begin{abstract}
Ikat textiles (kewatek) from Adonara, one of the Lesser Sunda Islands, are still seldom researched by textile specialists (Vatter 1984 [1932]; Barnes 1989). This article is the first account by a descendant from the island that builds on these studies to describe the social and cultural organization and taboos concerning ikat-dyeing and the weaving of kewatek in the twenty-first century. It also discusses recent government intervention and the actions of local NG O s to sustain Adonara textile identification and to stimulate the weaving of these sarongs for economic household purposes.
\end{abstract}

\section{Keywords}

ikat sarongs - social-cultural change - local NGO intervention - Indonesia - Adonara Island 


\section{Introduction}

'We have gathered to feed you; if we draw the wrong pattern then please correct it.' Weaving ikat sarongs (kewatek) in Adonara is seen not only as the creation of a new sarong, but also as an act directly related to the 'feeding' or the life of the island itself, and its population. The preparation of the thread and the weaving of traditional textiles is surrounded by taboos and occurs within the physical, social, and ritual context of the oe kenirek, a group of matrilaterally related women. Sharing their knowledge about techniques and patterns with outsiders, including an Adonara person from a different kin group, is until today regarded as asking for her death to the gods and ancestors. In Adonara's upland regions, warp-ikat sarongs are woven but not sold, particularly kewatek grara that are made within the confined space of the 'pattern group' or oe kenirek. In the coastal villages, more modern ikat textiles, produced with factory-spun cotton and synthetic dyes, are both produced and sold as a commodity to support the household economy. During the last decades, modernization and increased mobility have created incentives for the production of a large variety of new types of warp-ikat sarongs that increasingly replace the rare older ones, even at marriage and funeral rituals.

Data used in this article were primarily collected in the Witihama Subdistrict (kecamatan Witihama) of the East Flores District (kabupaten Flores Timur), especially in the village of Pledo. The Witihama subdistrict ${ }^{2}$ is considered neither coast nor upland, and consists of 13 villages. Three major clans have settled here over time: the Ile Jadi, whose ancestors are believed to be indigenous to Adonara; the Seran Goran, whose ancestors allegedly originate from the Moluccan island of Ceram; and the Sina Jawa, whose ancestors are supposedly from Java and elsewhere to the west of Adonara.

The people of Adonara belong to the large group of Lamaholot speakers in Nusa Tenggara Timor, Indonesia. They are closely related socially and culturally, sharing an important history of weaving warp-ikat sarongs, or kewatek, with other Lamaholot-speaking people living in East Flores and on the surrounding islands of Lembata, Solor, coastal Alor, Ternate, and Buaya (Barnes 1989, 1993, 2005; Wellfelt 2014). However, until today ikat textiles originating from Adonara Island have a rather low profile in Indonesian and international studies on ikat textiles. ${ }^{3}$ The small collection of literature mostly refers back

1 Tite pupu wekit ni ti kame pau boeke, nabe kame girek moi hala di mio gereko.

2 The subdistrict covers $77.97 \mathrm{~km} 2$ and has 13,626 inhabitants (Badan Pusat Statistik 2011).

3 Other techniques, like supplementary warp (menitit), were not part of this research. 
to the description of the island and its weaving traditions given by Ernst Vatter and his wife after their visit to Adonara in 1928 (Vatter 1984 [1932]). Half a century later, Ruth Barnes, who lived and worked among the Lamalera of Lembata, wrote a detailed study about the ikat textiles of Lamalera (Barnes 1989). She critically reviewed Vatter's detailed description of his Lamaholot textile collection, including a few kewatek from Adonara (Barnes 1989, 1993). Barnes states that 'Vatter [1932] claims that ikat (mowa) is unknown on Adonara. This is not correct: quite to the contrary, ikat warp bundles, already dyed and ready to be woven, are typical trade goods brought to the market by Adonara women [...] from the coastal villages, which traditionally specialize in trading' (Barnes 1989:106).

Given the poor state of affairs regarding knowledge of dyed ikat textiles in Adonara and their ritual and social value, it is high time that new knowledge on these kewatek from Adonara is shared with the wider academic and general public by providing a more detailed understanding of the past and present-day weaving of ikat sarongs on Adonara Island; government and NGO interventions; and the continuity and change of their uses on the island as well as in the diaspora. In this article we show how the history and the social-cultural context of weaving kewatek is far from homogeneous across the island and often bound by social and cosmological restrictions.

Three different kinds of kewatek are described, their variations including their names, the social and cultural value of the different sarongs in the human life cycle, and their changes during the last decades. In this article, the focus lies on the relationship between the weaver and her female matrilateral relatives; between the weaver and Adonara Island; and, ultimately, between the weaver and Adonara society in the diaspora.

Weaving is a living history (Duggan 2001), thus woven products bear meaning far beyond the technical process of production. In particular, a kewatek grara becomes the inalienable good of a woman (Weiner 1992), as it is never fully severed from its maker materially, morally, or socially. A weaver may present one of her kewatek to a male or female relative who ventures overseas. That person then gives that cloth the localized, particular identity of a 'biographical object' (Hoskins 1998:8) as the bearer of a shared Adonara identity. Hoskins developed the notion of biographical objects partly on the basis of Weiner's study on goods exchange in Melanesia. Cloth in particular makes a powerful metaphor to visualize the paradox of keeping-while-giving (Weiner 1992:153-4).

This article aims to present a short biography on kewatek as a part of the material culture and as a commodity in the rapidly changing Adonara society. It is therefore not enough to register that weaving techniques and knowledge 
have changed over time, but it is also relevant to document how material preferences and changes in the social, cultural, and economic context and conditions of weaving have shaped the relationships between the female weaver and the different kinds of Adonara warp-ikat sarongs, and how the use of these kewatek can tell something about their users.

The description of the technical and cultural aspects of the preparation of the yarn-and-warp ikat (mowak) of the kewatek is followed by a section describing the three main kinds of dyed ikat textiles in Adonara: kewatek kiwane, kewatek grara, and kewatek watane. The last section discusses how modernizing trends in the production and marketing of kewatek are initiated by the weavers themselves or through the intervention of the local government and NGOs. While knowledge of the various patterns of these traditional textiles remains the prerogative of older women, the younger generation of women is now being educated by local NGOs to produce ikat textiles for the regional market. Importantly, since the last decennia of the twentieth century, the cultural value and social meaning of warp-ikat sarongs have been rediscovered, particularly as Adonara identity markers for a younger generation living in the diaspora of Sumba, Java, and beyond.

Most textile studies on Indonesia are carried out by researchers from Europe and the USA. This article is the first study on Adonara textiles from within. The first author is of Adonara descent. She carried out fieldwork on weaving in Adonara and on the role of kewatek among the younger generation living in the diaspora (Somi Kedan 2013). Her investigations not only provide a highly relevant update on historical data from earlier studies on Adonara (Vatter 1984 [1932]; Barnes 1989), but also add to the body of anthropological and textile studies elsewhere in the region. ${ }^{4}$

\section{Technical and Cultural Aspects of Kewatek}

A kewatek is a cotton textile with patterns tied and dyed on the yarns (ikat). The Indonesian term ikat is widely used to describe the process by which a pattern is resistance-dyed on the weft and/or warp, before weaving begins (Niessen 1985:277; Hamilton 1994:70-3). A kewatek from Adonara is a warp-ikat sarong. In Adonara, knowledge related to the different activities, from the preparation of the thread to the ikat-dyeing and the actual weaving of the sarong, is still

4 Duggan 2001; Geirnaert 1992; Hamilton 1994; Hoskins 1998. 
considered sacred, as it is passed down exclusively among a woman's matrilateral female relatives. Until recently, the activities were carried out by this oe kenirek. ${ }^{5}$

The kewatek and its weaver are highly valued, as is evidenced from the following ritual text:

Jaga nuhut wewat, Kaka leit limat Nuwu wewa bera, Dolo delana

Numa neli moon ina bine

Maaro na naran data, Wauke doan

Mia nedan belehi, Witi kewatek

Witi teka taan puru nuhuket

Kewatek taan gabuk ro narane

Leim teku limam derep

Maaro mule lubak

Kewatek lowe

Ne mia goka witi kewatek
Watch your mouth, legs, and hands The mouth may speak (over)hasty, and instantly slip Abusing the woman

Ruining her name, as she becomes the subject of gossip

The penalty is a goat and a kewatek The goat will be eaten to tighten our mouth

The cloth will cover our good name The foot kicks, the hand hits Making the bun come loose The kewatek undone The penalty will be a goat and an ikat cloth.

This ritual text was recited in old, ceremonial language in the village of Pledo. ${ }^{6}$ It emphasizes the obligation of a man to be careful not to be rude to a woman, to guard her honour, and warns against verbal and physical abuse that may result in a fine - a goat - to be shared in a collective meal with the village and a kewatek as compensation for the woman.

Weaving a kewatek the traditional way was a discontinuous process which could take as long as three to five years. Of course, the work would often be interrupted. For example, weaving was and still is forbidden during the night. It

5 A grandmother may be the senior member of an oe kenirek, or matrilateral group, together with her sister, daughter, and granddaughter, irrespective of their marital status and whether they are co-residents or not. Meanwhile, her brother's wife, brother's daughter and daughterin-law belong to their (grand)mother's oe kenirek. In Adonara, access to land is passed down through the male line. Certain types of knowledge, especially related to kewatek techniques and rituals, are passed down matrilaterally. Husbands and sons are involved too, because they grow the cotton used by the women for weaving the kewatek on their land. Also, brothers are obliged to share some of the harvest with their sisters.

6 Interview with Ruslan Doni Kelogo alm, 23-11-2012. 
is said that the night belongs to the night creatures. ${ }^{7}$ Weaving is also forbidden when there is a funeral or a marriage ceremony going on in the village. Death and marriage are considered a call from lewotana, the motherland. Hence, even if they are not relatives to the people involved, the weavers should 'face the outside first, answer lewotana first'. Because, the women say, 'Still today, we have to keep lewotana in mind when we work.'8 Approximately sixty years ago, producing kewatek placed women in multiple relationships with the unity of Sun and Moon (Rera Wulan Tana Ekan) and with their ancestors, the society of the living, as well as with nature through their oe kenirek. During the preparations of the cotton thread that was produced and spun at home, the women related to the land of Adonara (lewotana). Through the weaving of the yarn on the loom they established a relationship with their community of weavers in the kuwu hut. At this stage, the young women would also establish relationships with the outside world, by engaging with men from other patrilineages near the kuwu. Today, the process of preparing the yarn for weaving takes approximately one week instead of three years. Even though the process is faster than in the old days, the weavers mostly respect the old prohibitions, for example, not weaving during the night or when a funeral or other ceremonies are taking place in the village. However, sometimes women were seen to be spinning before they went to sleep at night.

The process of making a kewatek includes five phases: preparing the cotton; spinning; skeining; ikat-dyeing, washing, and drying the bundles of yarn; preparing the loom; and, finally, the actual weaving on the back-strap loom (compare with Barnes 1989:14-46; Hamilton 1994:59-76). Preparing the cotton starts by harvesting the cotton from the fields of a woman's husband, son, or brother followed by the exposure of the cotton to the heat of the sun to dry. When dry, the cotton is put through the menalok (cotton gin or balok kapek) to separate the cotton fibres from the seeds. This work may be done individually or in a group. In the past, the next step of fluffing the cotton (buhu' kapek) was usually carried out collectively in a special hut called kuwu.

7 Ne orang rema perogo rak kerja rae, remakne rak raen. Various interviews, September 2012, Adonara.

8 Lewotana or tana ekan is the motherland, particularly the inhabited part of Adonara. A place without people is not lewotana, but a garden or field. 'Hadap plali belen ne kik, hadap lewotana kik, biar tite nimunet hala hadap plai belen ne ki. Bukan kerja taan masa bodo ne hala.' This is, they need to consider whether there are societal conditions that prohibit making a kewatek. (Group interview with Yustina Somi Kedan and Theresia Bulu Laga, 18-9-2012, Adonara). 
It is called gemohing kuwu or working together in the kuwu hut, the roof and wall of which were made of leaves and bamboo, with a very low door. Women were usually making an appointment to meet in the kuwu to work on everyone's cotton collectively. By the end of each day, they would distribute the clean cotton equally among themselves. The last time I saw a kuwu was in the 197os in the village of Watoone; we even had a song about it. $^{9}$

In the past, romance first blossomed around the kuwu. We called it tia $k u w u$. A boy would be waiting for a girl to finish her work in the kuwu, after which he accompanied her on the way back home while having a sweet conversation. ${ }^{10}$

The washing (bahak kapek) of the cotton thread was usually done at the seashore. On the way to the sea and during the washing the women involved were not allowed to talk to others. This cleaning was usually followed by a meal, called 'eating the new one' (or reka wuun), taken together by the women belonging to the same oe kenirek. Some older women said that they would also take a fragrant bath together, light a candle, and pray for their households to the unity of the Sun and Moon.

The washing, tying, and ikat-dyeing used to be accompanied by a prayer to protect the women and their households from the curse of the ancestors in case they made a mistake in the ikat patterning and weaving process. The women would pray: 'We have gathered to feed you; if we draw the wrong pattern then please correct it.'11 At the time of research (2012), it was still difficult to obtain much information about their activities because of taboos (see section on kewatek grara). But the technical data and pictures presented here were gathered in 2012. They closely resemble the descriptions and illustrations of the preparation of the yarn and the ikat-dyeing processes on Lamalera (Barnes 1989:27-32, 40-46) and other regional sources (Duggan 20o1; Geirnaert 1992; Hamilton 1994:59-73).

The spinning of the cotton thread is done with the use of a drop spindle (turek) made of wood, with a coin or betel nut attached at the bottom as a weight (Fig. 1). Sometimes the women would use the spindle while fetching

9 Interview with Veronika Lamahoda, 9-9-2012, Adonara Island.

10 Interview with Karolus Paron Lewan, 18-9-2012, Adonara Island.

11 Tite pupu wekit ni ti kame pao boeke, nabe kame girek moi hala di mio gereko. Bernadus Bima Raya alm., 20-8-2013. 


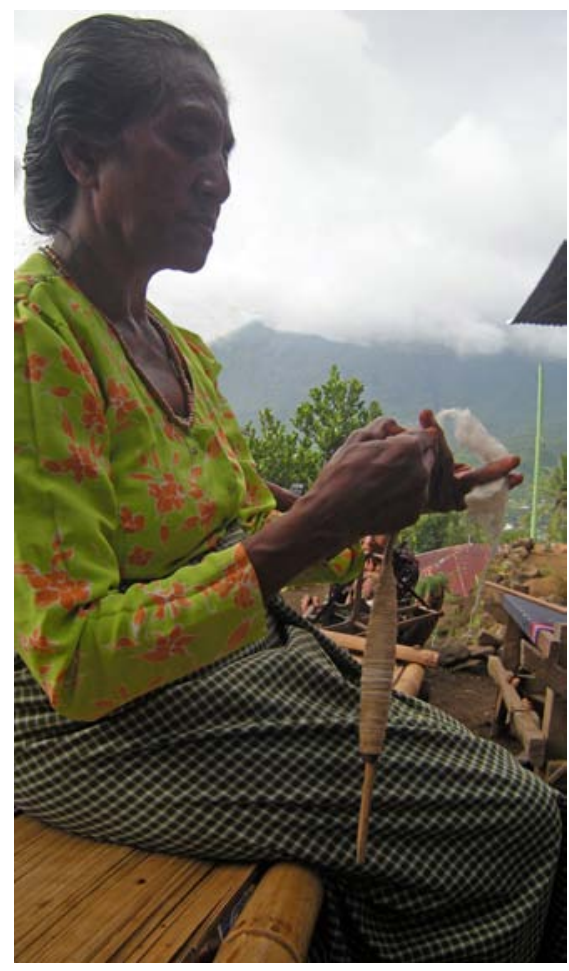

FIGURE 1

Spindle (turek lelu)

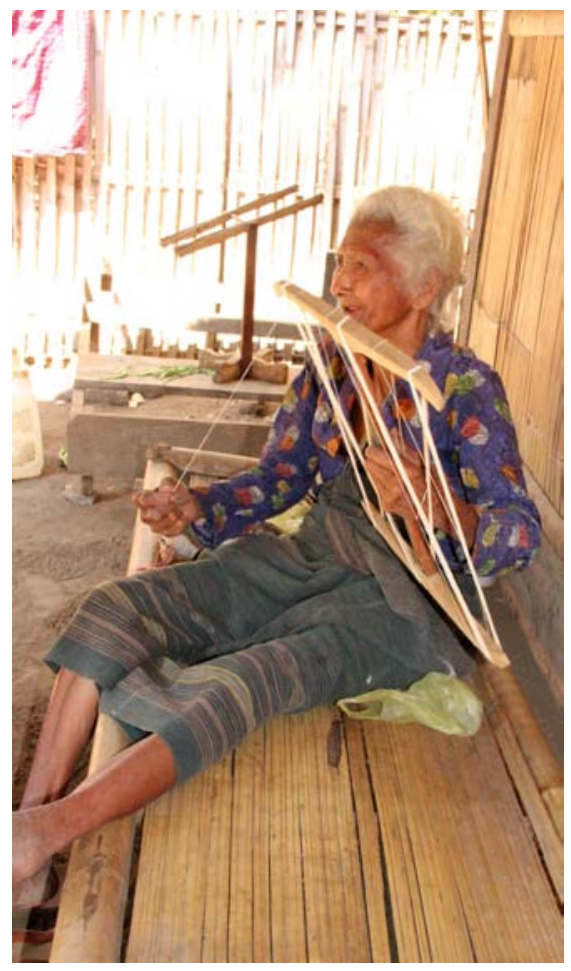

FIGURE 2

Reel (lawa bena)

water or during their informal conversation. A hand reel (belawa) is used for skeining the yarn (Fig. 2). The skeins are then ready to be dyed. After the skeins of dyed yarn are dry, the weaver places them on a swift ( $p u d u$ udu) made from wood with four 'eyes' (Fig. 3), each time using a different colour. The dyed yarn is then wound in a single, tight ball, an activity that is called tenurek. The dyed yarn is thereupon carefully arranged on the warp (neket) by winding the yarn continually from cloth beam to warp beam and back, thus arranging the differently dyed yarn according to the motif and pattern intended by the weaver (Fig. 4). Finally, the composition is tightly fastened onto the loom in an activity called tau, after which the weaver can start to weave (tane) the ikat cloth on the backstrap loom (Fig. 5). 


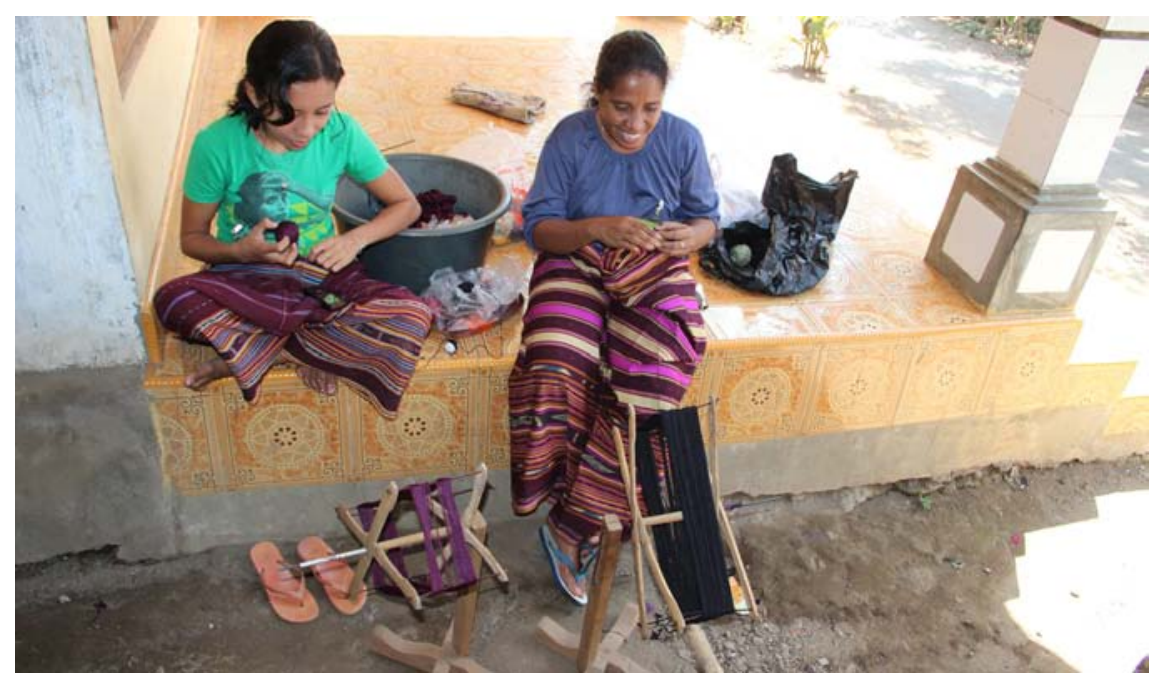

FIGURE 3 Swift (pudu udu)

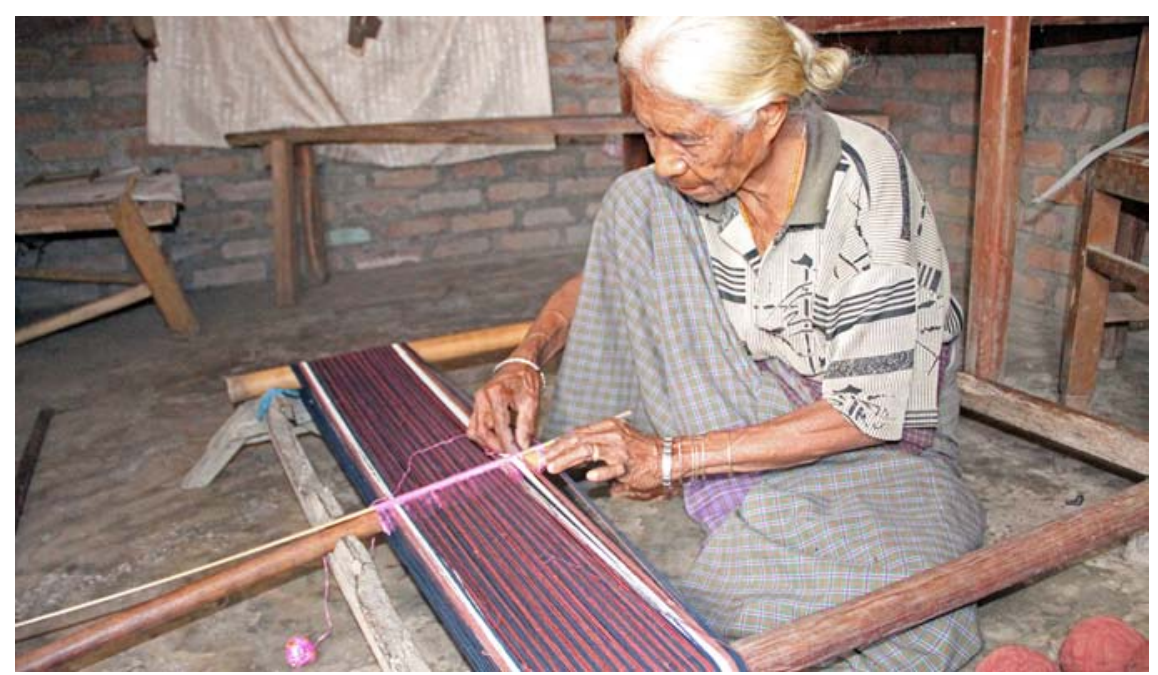

FIGURE 4 Setting up the warp (neket) 


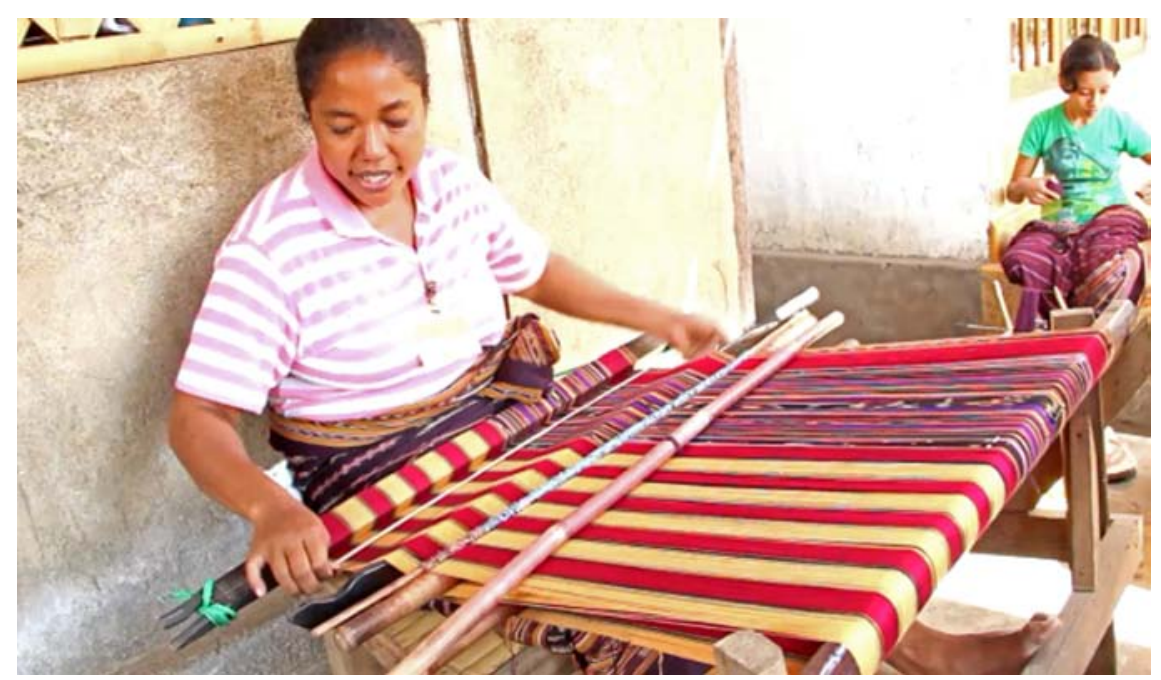

FIGURE 5 Weaving process (tane)

The weavers of the villages of the subdistricts of Witihama and Kelubagolit belong to the Demon group of people (Arndt 1938; Barnes 2001, 2005; Somi Kedan 2013). They often add locally dyed ikat bundles (mowak) to their warp. Kewatek with mowak from these villages can be sold elsewhere in Adonara and beyond, while kewatek made in the oe kenirek may not be sold (see below). Through several interviews, conversations, and focus group discussions, it became obvious that the coastal village of Boleng is well known as the producer of mowak. Our data confirm Barnes's observation (Barnes 2004) that indeed women from the coastal village of Boleng ${ }^{12}$ have the prerogative to produce and sell bundles of locally dyed yarn warp ikat (mowak), apart from producing and selling ikat sarongs (see also Barnes 1993).

There is one woman in particular who is recognized as the producer of the best mowak. People call her Ina Sedon Selami (Fig. 6). Her yarn is said to be

12 Boleng village on the coast is associated with the Paji group. Paji and Demon are historically different population groups that have a traditional rivalry (Barnes 2004, 2005). It was thus difficult for the researcher, who originates from a Demon village, to collect information from this famous mowak producer. She only had two opportunities to meet Ina Sedon Selami. 


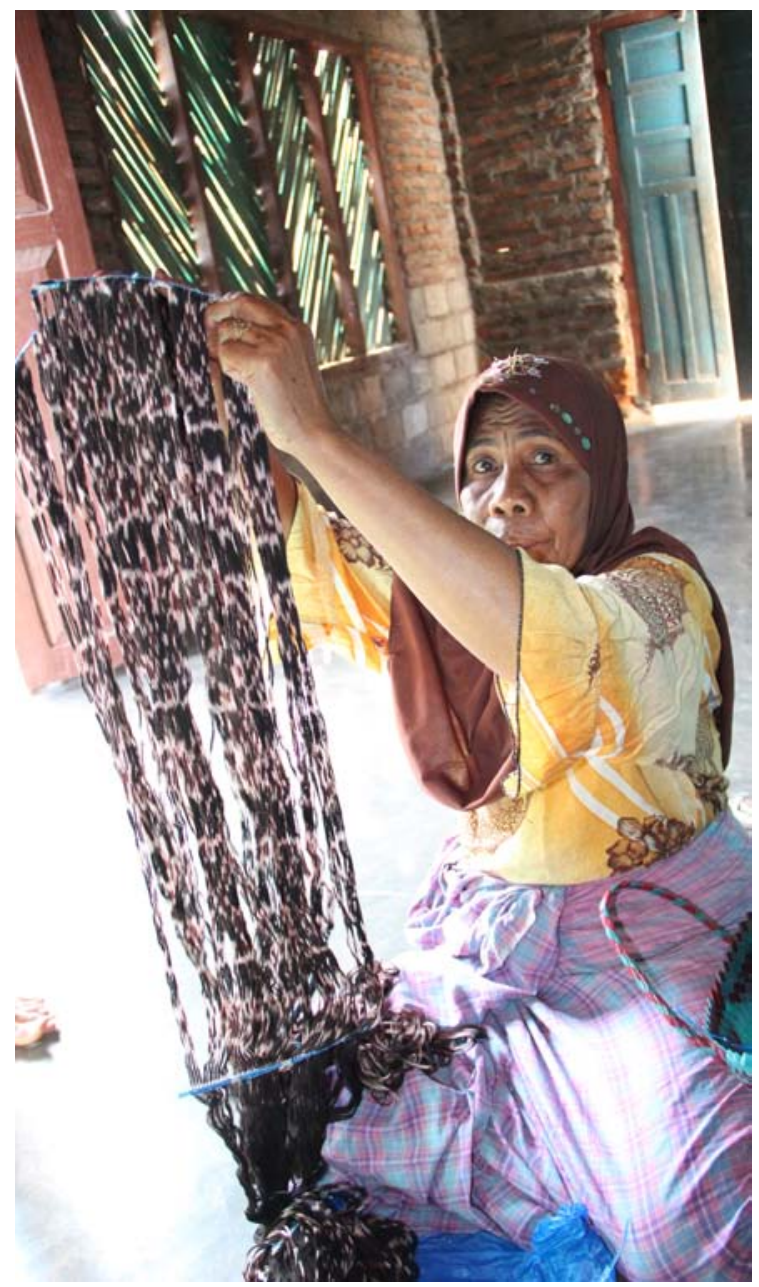

FIGURE 6

Ina Sedon and her mowak

stronger and not easily broken. She learned to make mowak from her mother and already accompanied her mother on her travels from one village to another to sell mowak when she was a child. Not every woman is allowed to sell mowak bundles, only women with asa. Asa is the specific knowledge of a clan and or individual obtained by virtue of inheritance. Ina Sedon Selami's asa was well known. ${ }^{13}$

13 For example, the power and knowledge to make ikat and sell it, to cure illness, to be a good carpenter. Today, Ina Sedon Selami's art of making and selling mowak has been taken up by her daughter. 
Kewatek from Adonara are warp ikats of handspun or imported cotton, dominated by red morinda (Morinda citrifolia) and indigo (Indigofera sp.) dark-blue dyes. The word kewatek usually glosses together female and male sarongs that are originally woven by using homespun cotton yarn and natural dyes. In the narrow sense, kewatek is the generic term for sarongs worn by women, even textiles that are not ikat-dyed. Nowin is the generic term for sarongs worn by men (compare with nofi for a man's sarong in Lamalera; Barnes 1989:49).

Weaving in Adonara is at the same time a technological-material, social, and cosmological affair (compare with Geirnaert 1992 on West Sumba). It contributes to the creation of Adonara and its people, and helps to sustain the wellbeing of both the people and the island. The weaver and her environment enter into a relationship with 'the Unity of the Sun and Moon, the Land of the Father and the Mother' (Rera Wulan Tana Ekan) ${ }^{14}$ (Somi Kedan 2013). Warpikat sarongs in Adonara have two major social functions. They are worn at ceremonial events, like marriages and funerals, both on the island and by the younger generation of emigrants to Java, for example. In Adonara, similar to Kédang but unlike Lamalera (Barnes 1989:52), kewatek are worn at funerary ceremonies. Secondly, they function as important exchange goods in marriage arrangements and as gifts for the dead.

In this section, three different kinds of kewatek and their named varieties will be described. This differentiation is based on the materials used and the meaning and cultural status attached to the textiles. Warp-ikat sarongs that can be woven by any Adonara woman are called kewatek kiwane and kewatek watane, as opposed to kewatek grara. The weaving of kewatek grara is restricted to a group of matrilaterally related women under the physical and social conditions of the oe kenirek and imposes certain taboos ( grara) on them. They should only use locally produced cotton made into handspun yarns and natural dyes, and their cloths should not be touched or used by persons other than the women of that group, who are bound by the oe kenirek ritual. Kewatek grara cannot be sold.

\subsection{Kewatek Kiwane}

Kiwane means original, indigenous. The word refers to the 'old ways', and to the land of Adonara itself, like in the title of Vatter's (1984 [1932]) book, Ata Kiwan. More specifically, kiwane refers to the upland. Kewatek kiwane is a sarong made

\footnotetext{
14 'The Unity of the Sun and Moon, the Land of the Father and the Mother' is the ritual formula that is used at the beginning of an adat-related activity. It speaks of the ancestors, of something glorious and great that is unattainable to mankind.
} 


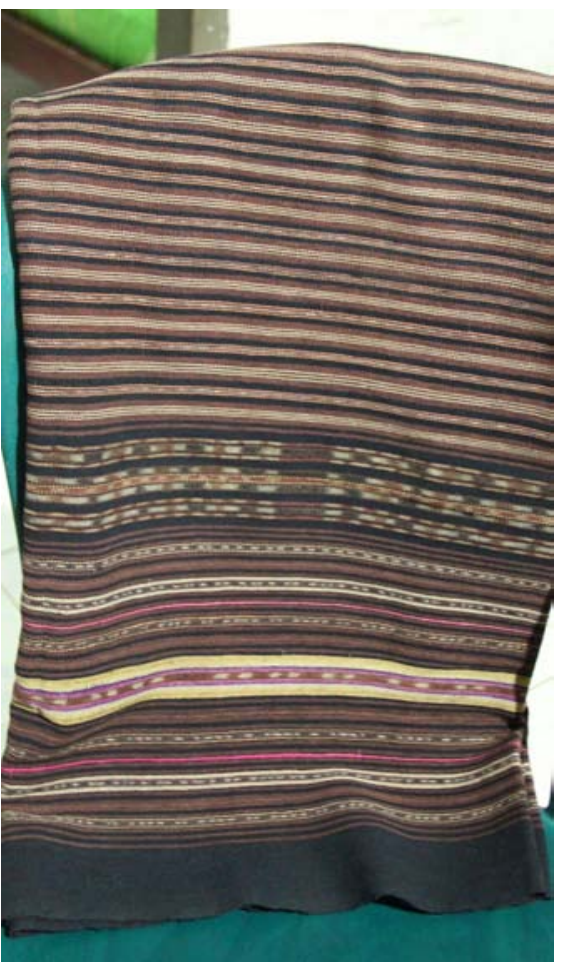

FIGURE 7

Tenopon telo with sunser-à

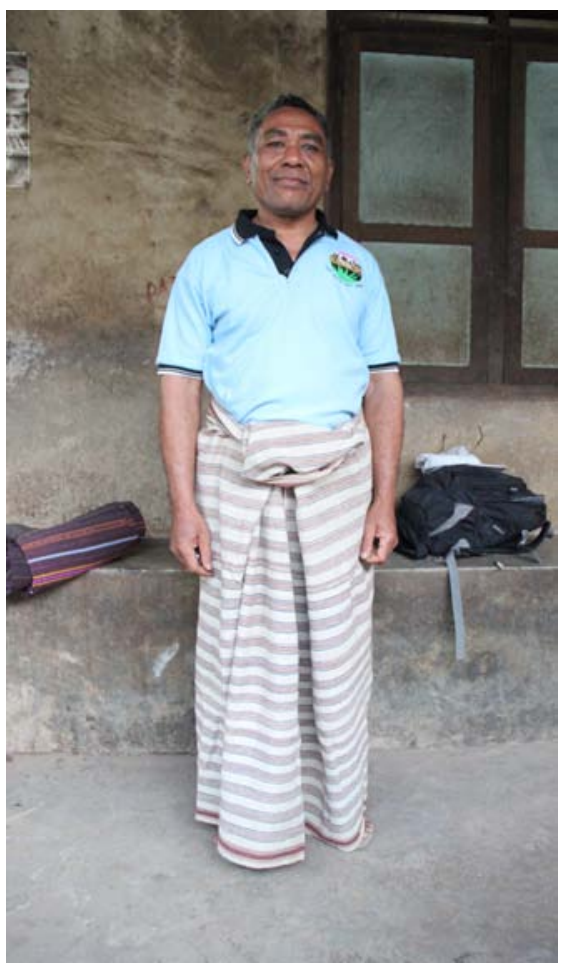

FIGURE 8

Kewodu

from handspun cotton that is grown on Adonara Island, and dyed with natural plant materials. Homespun cotton (kapek) is considered the main resource that has to be included in any communication with Rera Wulan Tana Ekan and the ancestors. Weaving kewatek kiwane thus means the involvement of the mandatory material, to pray, make decisions, and purify objects and human relationships.

The category of kewatek kiwane includes the following kinds of warp-ikat sarongs:

- Tenopon telo is the most important female kewatek for ceremonial use, particularly at marriages and funerals. It consists of three panels. When it is adorned with warp ikat of silk (sunser-à) it is called tenopon telo sunser-a. ${ }^{15}$ Presently, these older textiles are rarely found (Fig. 7).

- Kewodu is the name for a white sarong for men made of handspun cotton yarn and natural dyes. Kewodu is presently starting to disappear (Fig. 8).

15 See Barnes (1994:186) for two historical pictures of warp-striped sarongs with bands of silk from Adonara, including one from the village of Hinga. 


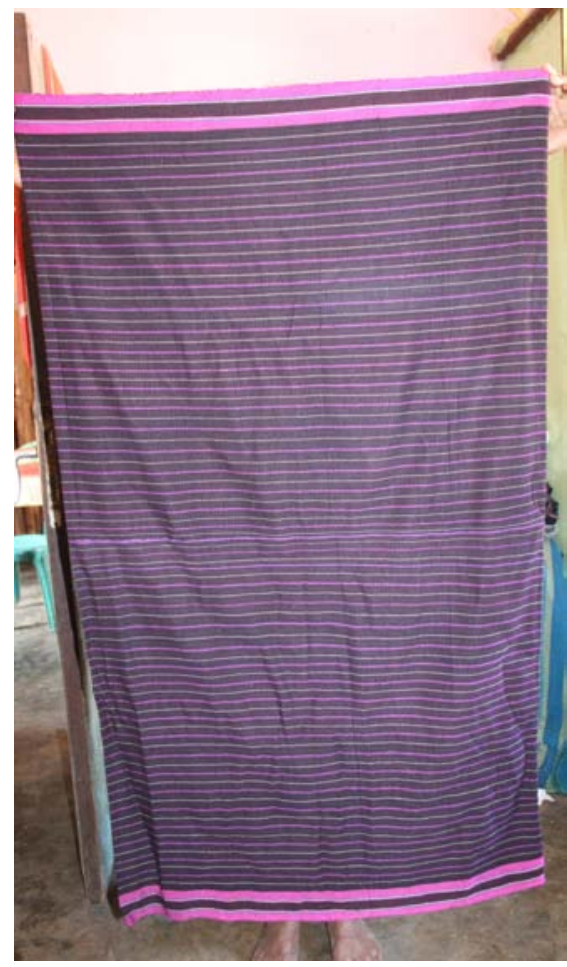

FIGURE 9

Nowin

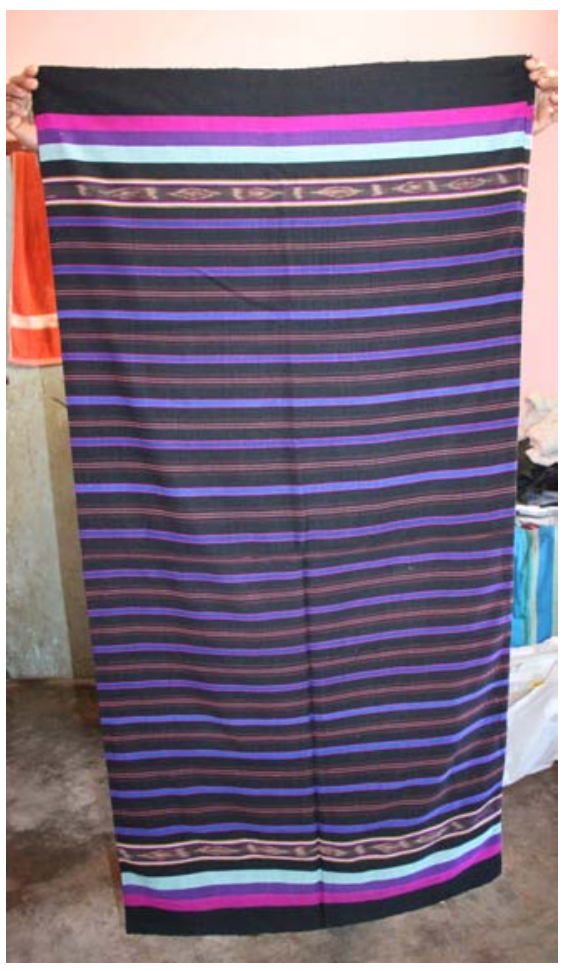

FIGURE 10

Heba Eha

Instead, weavers are producing nowin, the male cloth, that mostly has a dark purple-black colour made of machine-spun yarns and synthetic dyes (Fig. 9).

- Heba eha is a woman's sarong for daily use. Originally woven with homegrown, handspun cotton and natural dyes, it is now also made of machinespun yarn of handspun cotton bought on the village market or in town (Fig. 10).

\subsection{Kewatek Grara}

A kewatek grara is a kewatek kiwane that is woven by a woman in the confines of her oe kenirek. The women would gather in the oldest woman's house, in which the yarns, dyes, and all the equipment, including looms, would have been stored for the spinning, skeining, dyeing, and tying (ikat). The materials and equipment needed to create this kind of sarong are subject to taboo (grara) and can only be touched by a woman after the leader of the oe kenirek has said a small prayer to ask for the protection of the weavers of her group. This was 
usually done at the beginning of the harvest season in May or June. ${ }^{16}$ Brothers and sons would have helped the women by searching for the raw materials, such as the roots of the morinda, the indigo plants, and other natural dyes, as well as collecting cassava (ubi), cooking bananas, and coconuts for food and drink during the oe kenirek ritual. This is the time when the leader of the oe kenirek would call upon the ancestors (see footnote 14) with the words cited at the beginning of this article: 'We have gathered to feed you; if we draw the wrong pattern then please correct it.'

Once a woman decides to prepare the yarn for a particular ikat pattern and weave a kewatek grara, she is obliged to finish the sarong by herself. After all the necessary preparations have been made, the women start working in the seclusion of the oe kenirek. Women belonging to other matrilateral groups, who are bound by the ritual of their own oe kenirek, nor any man are allowed to come close to or talk with the women during the activities of the oe kenirek. They are not allowed to see and touch, let alone take pictures of the kewatek grara. ${ }^{17}$

The kewatek grara produced in the oe kenirek is a woman's inalienable cloth. Especially the ikat-dyed sarongs that are made with the use of homespun cotton yarns and dyes from plants grown in the fields of the husband, brother, or patrilineal cousin of the weaver. A kewatek grara has warp-ikat patterns that are only known to a particular woman and passed down to her daughters and granddaughters who belong to the same oe kenirek or 'matrilateral group' (girek, kenirek, see footnote 5), irrespective of their marital status. In the past, being able to weave a kewatek was the rite of passage of a girl becoming a marriable woman (Somi Kedan 2013). Kewatek grara are used at marriages and ceremonies, during pregnancy, during the rituals that mark the planting and harvesting of the produce of the land, and at any other occasion the owner of the sarong feels happy to wear the cloth.

Weiner, in her groundbreaking study on goods exchange in Polynesia, states how many highly prized cloths made by women can be guarded as inalienable possessions. They obtain a subjective identity, and by keeping these cloths as inalienable possessions while giving others away in exchange, a demanding economic and political commitment is developed (Weiner 1992:47). In the case of Adonara, the kewatek grara allows a woman to give away other kewatek.

16 A prayer was also said when the first author started asking questions about the oe kenirek: 'Forgive us, she is one of our grandchildren, she does not know anything; this is for her education.' Or: 'It is dogs and pigs talking, forgive her, she does not know anything, she is just like a baby.'

17 These rules have seriously restricted access to research data beyond the first author's own matrilateral group. 


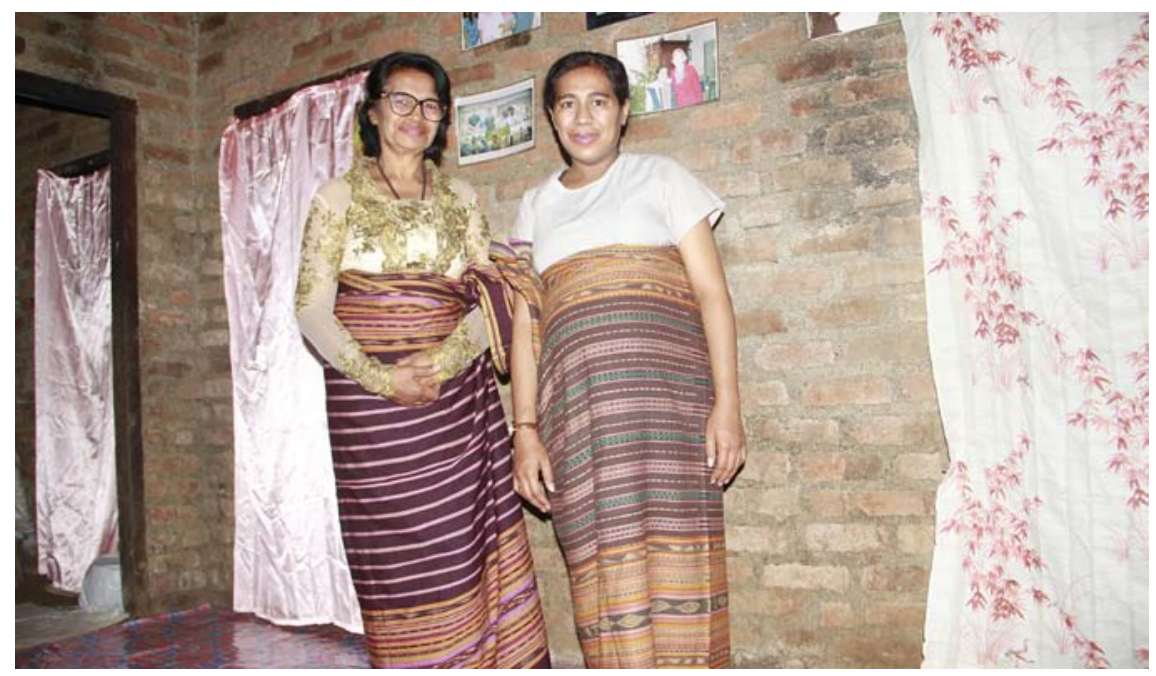

FIGURE 11 Kewatek grara

But unlike the kula exchange of Melanesia, the commitment demanded-or, rather, expected - in Adonara is more social and emotional than economic.

Sometimes, a kewatek grara is made by using machine-spun yarns or silk yarn is taken from old sarongs for the warp ikat (mowak). This cloth can be given by a maternal uncle to his sister's daughter at the occasion of her adat marriage. She is not allowed to take off the kewatek until the next day at the closure of the marriage ceremony. It then becomes her inalienable kewatek grara that cannot be worn by any other woman, not even her own sister, because it is a sacred gift that has a particular meaning in connection to a woman's pregnancy (Fig. 11). If another woman would wear it, this could have consequences for the ability of the woman who owns it to bear healthy children. It is also told that abandoning this kewatek could have consequences for the woman's ability to become pregnant again. At the occasion of the birth of a daughter, the father would make her a cotton gin (menalog) and a cotton bow (menuhuk) ${ }^{18}$ to be put in the bed next to the baby girl. As the daughter grows up, she will learn to weave. When a son is born, the father would make him a sword (kenubek) and spear (gala), and he will receive a nowin. The newly born child will use the kewatek grara starting from ore, the ritual meal he will take together with the ancestor from whom he inherits his name (Fig. 12).

18 See Barnes (1989:25-7, 141-3) for comparable names in Lamalera. 


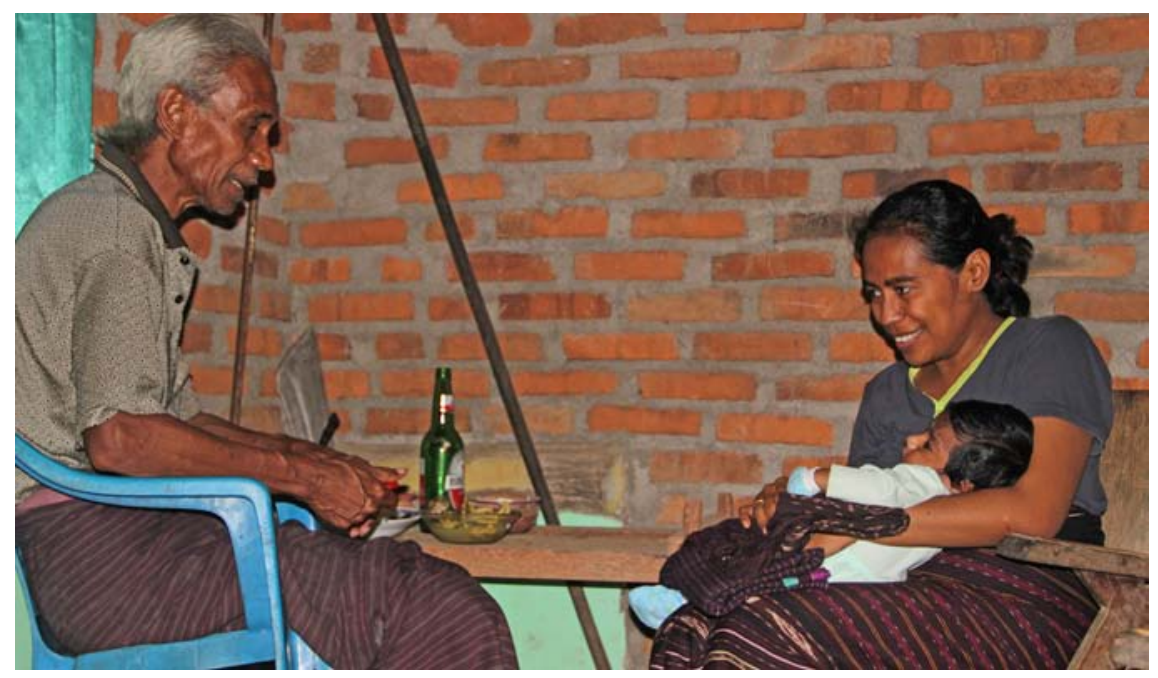

FIGURE 12 Ore ritual for a newborn son

A kewatek may also function, for example, as part of the payment for a fine (see above) or as an identity marker for a young man or woman who has moved to Java (see last section). The kewatek worn by an Adonara youth living in the diaspora may be used to make a cultural statement, but at the same time it is a means of conjuring up the personal memory (compare with Hoskins 1998:21) of the mother or grandmother back in Adonara, and keep the relationship alive to Lewotana.

In the past, kewatek grara were used as part of the offerings during bua hira, an adat ritual held at the start and the end of the planting and harvesting season at which the family shares food together with the ancestors to praise and pray to the ancestors. Below we present the text of the main prayer, recited by R.D. Kelogo in the village of Pledo. ${ }^{19}$

\section{Lodo ola lali duhli maaro ihik} wuana

Wuana di go ma peten, gere here heti lewo

Maaro wai emaka, di menu maan kepae
A man goes to the field to make the crops ready for harvesting

He eats the harvest wisely; a man walks uphill to the village to collect the water; he drinks it wisely

19 Interview with R.D. Kelogo alm., Pledo village, 23-11-2012. 
Lodok deket lali duli, gere kewasano heti lewo

Bua hira toon bine kaka nohlo murine

Epe eti wahak kamá, watak mua, wewe, uta, alek

kewatek, labu, kala, bala muko, tapo

Kotek ka poo oho hebo, Aleka butek tena geneek.
Down to the field he is a soldier; climbing up to the village he has the power

The ritual of eating together with the younger and older sister Offering the maize, rice, lentils, red beans, kewatek and other cloths, bracelets, tusks, bananas, and coconuts Washing their dull hair, changing their old cloths.

Oe kenirek in the sense of a group of related women coming together at a particular time and space seems to become more and more an element of the past. Increased mobility of its members, not only within but also outside Adonara to other islands, presently makes it more difficult and costly to get together to produce sarongs bound by the oe kenirek ritual. But in terms of cultural values, the oe kenirek still imposes the notion of taboo or restrictions on the making of kewatek, even in the case of commercialization. This may sometimes lead to awkward situations. For example, a weaver from the village of Lamabelawa in Witihama subdistrict told the first author during a government workshop that she could not touch the morinda dye prepared for the workshop, because morinda roots are used in her oe kenirek as well, and at the workshop no ritual had been performed to protect the women.

\subsection{Kewatek Watane}

When in the twentieth century machine-spun cotton and synthetic dyes became accessible to the weavers in Adonara, weavers started producing modern kewatek or kewatek watane. Younger women nowadays prefer to weave kewatek watane to kewatek kiwane. Since the 198 os, the island has become more accessible and thicker, handspun cotton thread from Maumere and machinespun cotton thread from Java have become available at village markets and in the capital Waiwerang. Women have begun to create a wide variety of sarongs using combinations of locally produced dyes and handspun cotton as well as machine-spun yarns and synthetic dyes, while they often improvise, using older patterns as their inspiration. Sarongs continue to be woven with warp ikat (mowak), using either home-spun yarn and natural dyes or yarns and dyes bought from Boleng. For example, the highly valued kiwane tenopon telo may now be woven from machine-spun thread, a qualitative change that is expressed in the new name for the cloth: watane tenopon telo. If it is woven in 


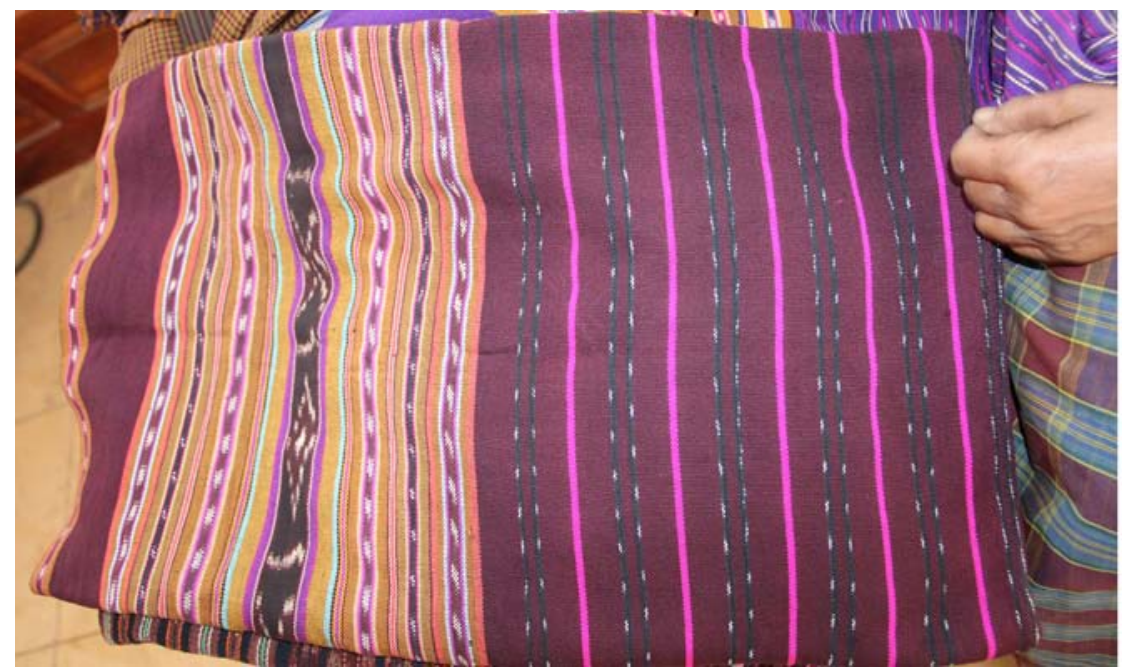

FIGURE 13 Demo pari

combination with the silk thread taken from an old sarong, it is called tenopon telo with sunser-à or simply sunser-à. The old sarong is taken apart to expose the silk yarn.

Other kewatek watane or modern sarongs are called demo pari (Fig. 13), heba belaha, wato witi, and karo kumha. A kewatek watane without warp ikat and solely made of machine-spun threads is a penetote (Fig. 14). The weaver here uses the supplementary warp technique (see Hamilton 1994:73-5) to create the pattern.

Contrary to the prohibition on selling kewatek grara, the sarongs woven with the use of natural dyes and home-spun cotton by the women of the various matrilateral oe kenirek, there is no restriction to selling sarongs woven with the use of machine-spun cotton and synthetic dyes from the stores. Today, one can find this kind of modern ikat textile, kewatek watane, in most of the markets in the villages and in the district market in Waiwerang. People may also buy ikatdyed textiles from the weavers' group or at the house of one of the weavers. of Kewatek

Weaving has always been closely intertwined with Adonara village and the household economy. People in Witihama recall the economic crisis at the end of the Sukarno era in the 196os, a period locally called malu mara, during which 


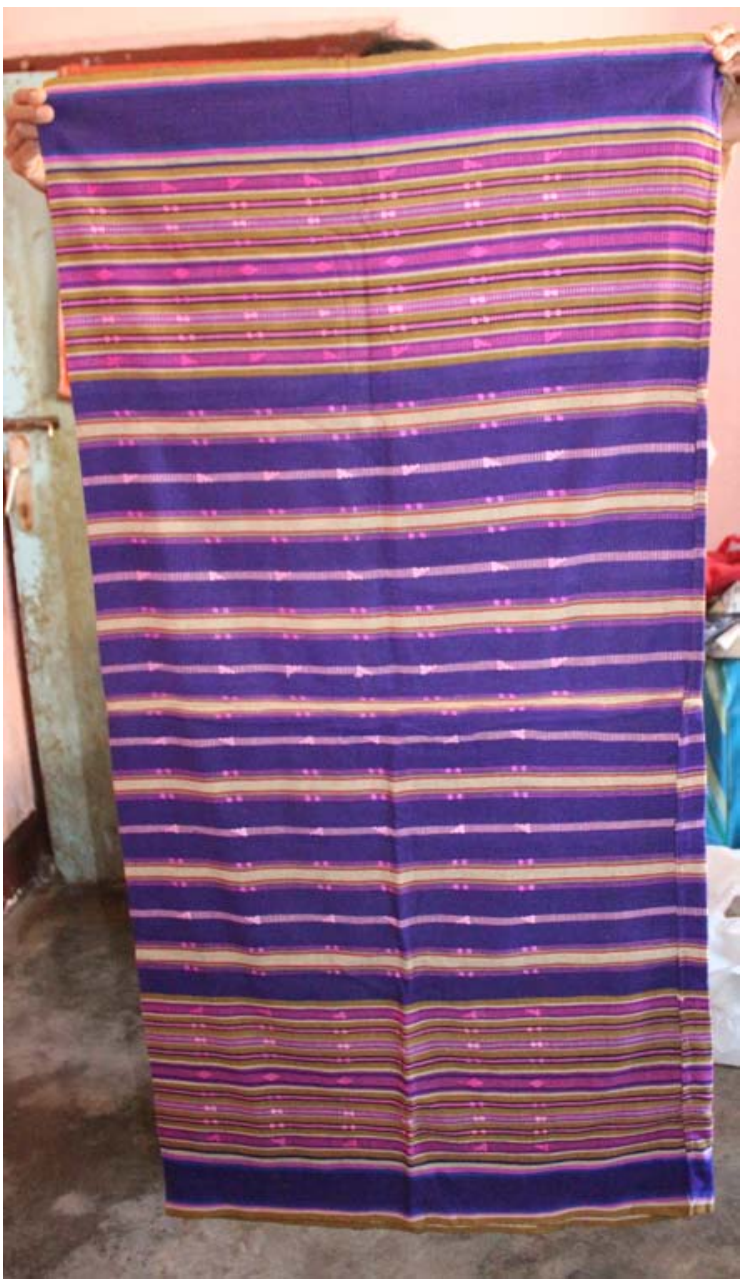

FIGURE 14

Penetote

there were severe shortages of food and clothing. During the 1970s, Adonara society changed considerably when social and economic mobility increased both on the island and to Sumba, Java, and beyond. Many younger people migrated for work to Batam and Malaysia, and upon their return they brought new clothing fashions. The traditional weaving culture concentrated around the kuwu hut and the matrilateral pattern groups bound by the oe kenirek ritual started to disappear, first in the coastal areas. During the 1980s, the differentiation between the coastal villages and the upland or udik villages started to become more pronounced. Wearing traditional sarongs for daily use became associated with backwardness. In coastal villages, new patterns were designed for modern sarongs (kewatek watane) woven with machine-spun yarns and 
synthetic dyes, and sold at markets within and outside Adonara Island. Increasingly, individual women took up weaving for commercial purposes to add to the household income. In the upland villages the kewatek grara were kept for exclusive use within the women's matrilateral oe kenirek groups.

By 2012 the whole ikat process in preparation for the weaving, and the use of the kewatek already involved multiple actors. Starting from the weavers and the women selling the textiles, also the regional government and local NGO s had become instrumental in transforming kewatek kiwane and kewatek watane into a commodity. Moreover, their interventions stimulated the revival of kewatek as an identity marker for Adonara Island and its people. At the same time, a public debate had started on local government policy concerning the adat practice of the ostentatious display of large numbers of kewatek at marriage and funeral ceremonies (see below). For example, in the subdistrict of Witihama a new regulation was issued that restricted the number of kewatek exchanged during adat ceremonies. It was met with both support and opposition. Meanwhile, the neighbouring subdistrict government of Kelubagolit did not impose such restrictions.

There were only a few local NGO s in Adonara, born out of discontent with the local government's lack of effort to support and sustain the tradition of kewatek weaving, like the Tana Ile Boleng Foundation. ${ }^{20}$ One of the founding mothers of the organization stated that the government mainly supported groups of weavers by providing them with credit through the Dinas Perindustrian dan Perdagangan (Department of Industry and Trade) to boost home economics but that they had no interest in the cultural and historical value of kewatek. She was also afraid that the formal limitation of the exchange of kewatek to weddings and funerals might endanger the revenues of those women whose income depended on the sale of kewatek.

Several local government programmes intended to increase household revenues, such as the programme to financially support the economic activities of female-headed households, called Perempuan Kepala Keluarga (PEKKA). The Kelompok Usaha Bersama (KUBE), or business group programme, was initiated by the Dinas Sosial (Social Department) at the provincial level to support small-scale businesses of both men and women based on the production and marketing of kewatek. In 2012 these included as many as 392 units of weavers. In Witihama village alone there were 6o units; in Pledo village there were five (Sensus Penduduk Witihama 2012). For example, the group Nulu Balik in Witi-

20 This organization did not sell dyed ikat yarn or textiles but trained women, for example, to become project facilitators. 
hama produced kewatek for the purpose of commercial trade. Meanwhile, the activities of washing, ikat-dyeing, and drying the yarn remained being done collectively by the oe kenirek-even if it was becoming increasingly difficult to gather all the women belonging to one pattern group in one place at one time, due to the increased mobility of the younger generation.

Despite its positive effect on the weavers' household economy, the implementation of the KUBE programme also had some drawbacks. Like its leader noticed, local conditions appeared to be neglected or not considered to be important by the government. The first problem is village politics. The government did not keep good control over how and by whom the small-scale business programme was executed. Local politics tended to provide room for nepotism in the case of development projects by favouring projects that were managed by those who had family ties with the local authorities. Projects related to the commoditization of kewatek are no exception. Also, a closer monitoring and evaluation is needed to assure that project funds are used appropriately.

The second bottleneck is the cultural aspect of the weaving projects. Financial support of the manufacturing of kewatek did indeed bring material improvements. But the cultural aspects of weaving were neglected, like the importance of the role of the oe kenirek. Project objectives should be broader than merely focusing on the economic aspect of kewatek as a commodity by also considering the wider social and cultural context and conditions of weaving kewatek. The following excerpt from field data shows the close interrelationship of weaving and the everyday household tasks of an Adonara weaver:

Yustina Somi Kedan is a 40-year-old woman and the head of her household since her husband's death several years ago. She starts her days at $4.00 \mathrm{am}$; she first bakes maize cakes and fills the water container in the house. At around $6.00 \mathrm{am}$, she starts to prepare breakfast for her family and gets her 14-year-old son ready for school. Sometimes she also prepares a herbal drink for herself to reduce the pain in her back that she feels because of too much sitting and working. After that she continues to prepare corn cakes because sometimes someone will buy them from her for a small amount of money or sometimes people just barter the cakes for more grain. At around 8.00 am she goes to the field to feed her cattle. After that she prepares herself for the day. Each day, she combines the activities of weaving, working on the field, and food preparation. Sometimes she weaves first and then works in her field until around $7.00 \mathrm{pm}$, but on other days she goes to the field directly and sometimes she just alternates between weaving and cooking for the whole day. At around 7.00 pm she feeds the cattle again and starts to prepare dinner. In the evening, she 
sometimes joins the Catholic prayer group in the village, otherwise she cleans her house, refills the water container, prepares the yarns for the next day's weaving or deals with the food crops she has brought in from the field. This work schedule will of course change whenever there is a ceremony in the village. ${ }^{21}$

The role of kewatek in the twin process of mobilizing and modernizing Adonara society shows the continuity and change of the value and meaning of kewatek both within and outside Adonara Island. The expression 'looking for the larger corn' (seba wata bele) is applied to those Adonara men and women who have left their home village in search of a better life. For example, the first author's grandfather left Redong, his original village located in Kelubagolit subdistrict, to go to Lamaleka, a village in the Witihama subdistrict of East Adonara. When the first author asked her family 'why her grandfather had left Redong', they answered: 'He went to look for larger corn.' (seba wata bele). The same expression of 'looking for the larger corn' also became her answer to one of her father's sister's sons, when he asked why she had moved to Wageningen for her graduate studies. 'Travelling that far, what are you looking for?' She replied, 'I am looking for the larger corn, I go seba wata bele'. His mother was astonished and, looking at her, said, 'The road will be tough, how tall do you want it to be?' The first author replied while pointing at Ile Boleng, 'I want to be like her, as high as she is, as low as she is. Ever since that day, the first author has tried to have expectations as high as the Adonara volcano Ile Boleng and to make them come true in her everyday activities. The expression seba wata bele applies to all Adonara migrants, whether they are moving within the island, nationally, or internationally beyond Indonesia, to maintain their relationship with their village of origin (lewo). No matter how far they travel away from their village, an Adonara person will always try to go back to his/her former village and put on their best cloths in order to attend marriage ceremonies and funerals to show their attachment to their place of origin (gelekat lewo).

Some 30 years ago, Adonara people would just consider kewatek as their clothing. Yet, the number of cloths was limited since the process of creating one piece of kewatek would take almost three years. In those days, people were using tenopon telo for major adat ceremonies and heba eha for daily life to cover their body from chest to ankles. When factory-produced textiles were introduced by the 1930s, people started to use the new clothes in combination with kewatek.

21 Field data based on participatory observation of the first author in the village of Pledo from September to November 2012. 
Nevertheless, the number of new clothes was also limited. Often a family member only had two pieces. Furthermore, in Adonara society the newly imported factory-produced clothes were considered to be a luxury good that was affordable only to members of the higher social class. If a woman from the lower social class wore such clothes this was publicly frowned upon:

When my mother first wore factory-produced clothes, she was laughed at by her friends; they told her that such clothes were the prerogative of the 'big people' (ata kebelen). ${ }^{22}$

However, despite the new fashion taken home by the younger female generation, kewatek kiwane are now becoming trendy again on the island. ${ }^{23}$ Islanders now start searching and using the kewatek kiwane that they used to consider an ugly and uncomfortable cloth, because they start to realize the scarcity and the value of kewatek kiwane.

Today, a girl's rite of passage to womanhood does not oblige anymore that she is able to weave kewatek in order to obtain the social permission to get married. Changes in weaving techniques also occur within the organization of the oe kenirek itself, since the women start buying the yarn instead of growing and harvesting cotton for the oe kenirek ritual themselves. Some weavers consider these material changes to be the effect of cultural change in the sense that women nowadays prefer to do something with less effort and difficulty (sinha sesak):

Kenirek has changed considerably, because everything is now collected by buying the materials. I do not know why it changed. The elderly people said it is because of sinha sesak. Like today, we only see the good side of it. We only want life to be easier. We don't want to sit and get our backside dirty, we only want to have fun. ${ }^{24}$

Demands for kewatek usually significantly increase at the occurrence of funerals and marriage ceremonies. Adonara women have recently started to weave kewatek applying the fine machine-spun yarn that is used in sewing factoryproduced clothes. Several women have started to sell kewatek watane at Mirek, the traditional market of Witihama subdistrict, while others keep them within

22 Interview with Ina Kewa, 18-8-2012, Lamaleka village, Adonara Island.

23 Interview with Ina Kewa Warrak, 22-8-2013, Lamabelawa village, Adonara Island.

24 Group interview, 21-9-2012, Pledo Village. 
their weavers' group and the buyer would come to the group to purchase the kewatek. At this island market, Adonara kewatek have to compete with ikat textiles from Ende and Maumere that are considered more valuable and are sold at a higher price. In 2012, a kewatek woven with locally produced cotton and homespun yarns would sell at about 300,000 IDR, while kewatek woven with a combination of homespun cotton and cotton from Ende or Maumere, or a fully finished ikat sarong originating from Ende or Maumere, would sell at a price of about 700,000 IDR. In several cases local kewatek were sold side by side with ikat textiles from Ende or Maumere. Depending on the kind of adat ceremony, these textiles from outside Adonara can be worn, for example, by guests at a wedding or funeral but not for adat rituals such as ore (Fig. 12).

Meanwhile, outside of Adonara Island there are no specific markets. Instead, individual traders or professional organizations provide access to markets elsewhere. ${ }^{25}$ Also, younger migrants have now started to use Facebook to market ikat textiles. ${ }^{26}$ However, there are several reasons why kewatek have not broken through into markets outside Adonara Island in big numbers. First, the weaving process takes time, and the weavers only manage to fulfil the island's internal demands. Second, there is no individual or institutional trade network, and third, Adonara weavers and traders have little self-confidence when it comes to selling kewatek from Adonara. One weaver expressed this feeling by saying: 'People in Hinga consider the cloth we sell to be made of second-rate yarn. Their yarn was dyed.' Adonara women have the impression that their sarongs are less valuable than those from Maumere or Ende because homespun yarn is used, and they show fewer mowak or ikat-dyed patterns.

Recently, weavers in Pledo village have begun to discuss the revitalization of kewatek production. The women are interested in rehabilitating the weaving of kewatek kiwane and building revival strategies for this kind of ikat cloth. They recognize the need to return to the old techniques of ikat-dyeing and weaving kewatek kiwane, because for them the main reason for weaving the cloth lays in the preservation of their weaving tradition. They have realized that by leaving their ikat activities behind, they have not provided an incentive for the men to keep up their cotton plantations and the growing of natural dyes.

Kewatek kiwane are now not so easily sold because the women have started to view them as precious heirloom cloths. Due to the scarcity of the materi-

25 In 2019 one trader was selling kewatek from Adonara as far away as Tanah Abang, Jakarta. 26 Interestingly, during a visit in 2018 the first author observed the increasing use of kewatek watane that are produced by the younger generation in the creative industry. They use social media to share how proud they are wearing kewatek and to promote their creative weaving of kewatek. 
als needed and the long process of ikat-dyeing and weaving, they have started to reconsider the cultural and economic value of kewatek kiwane. Meanwhile, several women have started to sell their bundles of handspun yarn from locally produced cotton, but under several conditions. First, they will not sell it in a public market; they store it in their houses and sell it only when someone comes to the house to purchase it. Second, only the monochromatic skeins that have been languishing in the house for several years will be sold.

However, most weavers still prefer kewatek watane over kewatek kiwane. Firstly the weaving of kewatek watane takes less effort. Secondly, the increased availability of modern materials, like machine-spun yarns and synthetic dyes, on Adonara Island makes the preparation of the warp far less time-consuming than the ikat-dyeing process. Thirdly, the use of machine-spun yarns and synthetic dyes has also been stimulated by changes in land management. Adonara farmers today are more focused on planting cashew nuts as a cash crop and on developing other agribusiness-types of plantations. However, this shift in land use comes at the expense of the land needed for the cultivation of cotton and natural dyes.

Several older women were concerned that failure to continue their weaving of kewatek would make their village more vulnerable, because of the absence of the growth of natural dyes and cotton trees. They believed that the cultivation of food crops like plantain and cassava, together with their expertise of harvesting cotton and the resources of natural dyes, creates and supports the life of Adonara Island and its people, and safeguards and protects their village against sickness and disaster. In other words, weaving kewatek kiwane is closely interrelated with the health of the village and its community. Realizing the changes in traditional warp-ikat-weaving, several women have started to weave kewatek kiwane again. They consider it a social and cultural obligation: 'Weaving the kiwan yarn, even if only once in every five or ten years, we have to weave it, we cannot neglect it.'27 Some have also started to pass on their knowledge and ability in weaving kewatek kiwane to their daughter(s) to safeguard the future of Adonara kewatek. Other women have started to teach younger women because they believe that the younger generation of weavers needs their technical support and cultural mentoring to produce the right cloths.

Particularly in Witihama subdistrict, government intervention regarding kewatek resulted in a regulation to limit the financial burden of adat ceremonies involving the exchange of tens or even hundreds of cloths. In September 2011, an Agreement on the Adat of Burial Purification (Hasil Kesepakatan 
Pemurnian Adat Kematian 2011) was discussed and signed in Witihama. The agreement was initiated by the organization of retired government functionaries, Ikatan Kelompok Pensiunan Witihama (IKPW), which saw the elaborate funeral ceremonies as a burden to the family. The agreement was the result of several meetings, first with the government in September 2011, followed by a discussion with adat and religious leaders in October 2011, and finally a discussion with the village's women's group in November 2011. The agreement is presently being processed to become a legal component of village regulations (Peraturan Desa). The ostentatious display of cloths was considered an excess, creating conflict between families who would compete to increase their social status through the exchange of large numbers of kewatek. It had become regarded as a waste that deviated from adat rules and needed to be properly restrained. Nowadays, instead of bringing hundreds of kewatek, people are only allowed to bring between one and three kewatek, depending on the social status of the deceased and one's family relationship to him or her.

Weavers did not agree with the new regulation, because it threatened to reduce their income. They feared that a restriction on the obligatory exchange of large numbers of textiles at marriage and funeral ceremonies would reduce the demand for kewatek and negatively affect their household income at the expense of their children's education. They explained that the limitation on the number of adat cloths was especially contested by families who could afford the exchange of large numbers of kewatek and who were engaged in a long-standing network of exchanges between relatives and affines that could not be broken by just one government rule. Those who had already given a large number of kewatek in the past also opposed the new regulation out of fear that it would reduce the amount of cloths they were entitled according to adat to receive in return. The new agreement on the restriction of kewatek exchange would thus cause the breakdown of such multi-purpose kinship networks. Most of these protests came from the villages of Redong and Watoone, while in Koli, the government reacted by putting sanctions in place for those who did not comply with the regulation. Fig. 15 shows the presentation of kewatek at a funeral in the village of Redong in Kelubagolit subdistrict on 16 August 2012, at which the agreement to limit the number of kewatek was evidently ignored. However, according to the village head of Pledo in Witihama subdistrict, the value of kewatek itself has not changed, despite the material changes of using machine-spun yarn instead of homespun cotton and the changing use of kewatek, for example, during marriage ceremonies. ${ }^{28}$ 


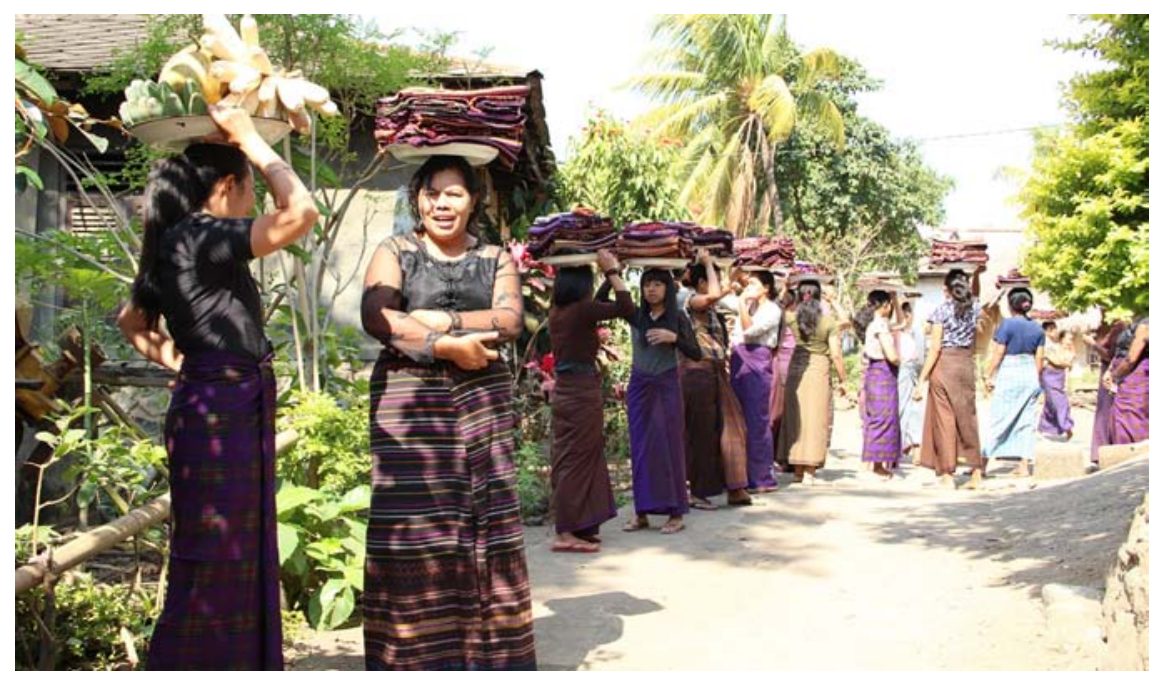

FIGURE 15 Funeral ceremony in the village of Redontena

Kewatek have started to play an important role in migrant identity. On an individual's departure to the diaspora, his or her family presents him or her with only one cloth, a kewatek for a woman or a nowin for a man, to sustain the cosmic relationship with their island of origin. During a focus group discussion (FGD) about their knowledge, experience, and valuation of kewa$t e k$, the majority of the ten members of a student organization from Adonara (GEMA) ${ }^{29}$ acknowledged that they felt proud, impressed, and interested in kewatek, whether kewatek kiwane or watane, as both cloths are considered part of their Adonara identity. Only one girl admitted that she did not really like kewatek because she felt uncomfortable wearing it. Similar experiences were shared by Adonara migrants in Yogyakarta, where an FGD was held with several students from Adonara on 19 October 2012. Two men and three women who had been involved in the weaving of kewatek were present. Two of the women came from Redong and had participated in oe kenirek activities when they were younger. They felt proud of kewatek as part of their identity. However, both the men and the women felt uneasy at the idea of having to wear nowin or kewatek, respectively, on public occasions in Yogyakarta. They admitted that in daily life they preferred to wear batik over ikat sarongs. Kewatek would be used

29 Focus group discussion in Surabaya, 15-10-2012. The Generasi Muda Adonara (GEMA) organization in Surabaya is an organization of young people, mostly students from Adonara who live in the diaspora of Surabaya. 
only at special occasions, like gift-giving, and during traditional dance performances, at a wedding party, or during graduation. Sometimes they would use it as a shawl on campus, or at a student demonstration. For example, when GEMA was involved in a public demonstration to call on the younger generation to reflect on the memories of the national heroes, several Adonara students were seen to be wearing nowin and kewatek. Above all, they all felt that their kewatek was a precious good that symbolized their self-identification with Adonara Island and its people.

This article presents research data gathered in 2012 by a female MSc student of Adonara descent about the production process of warp-ikat sarongs, or kewatek, and their historical, cultural, and economic meaning (Somi Kedan 2013). Also, it is the first article on Adonara textiles since Barnes's research in the late 1980s and Vatter's visit to the island in the early twentieth century. In Adonara, the preparation of the yarn, ikat-dyeing, washing, and weaving process is carried out in accordance with strict taboos (grara) by a group of matrilaterally related women belonging to an oe kenirek. The first author was allowed to share in her grandmother's group's knowledge about weaving kewatek, although this very social position also restricted access to knowledge from other groups. While access to land is passed on through the male line, knowledge about the techniques and rituals of weaving is passed on matrilaterally from a woman to her daughters and daughters-in-law, irrespective of their marital status and residence. Men have a complementary but more indirect technical role in the manufacturing of kewatek. They provide the land to plant the cotton seedlings from which the sarong is woven, and some members of a particular clan are good carpenters specializing in making the loom. Also, the mother's brother presents his sister's daughter with a kewatek at her marriage, but men are not allowed to come near the process of making a kewatek in the oe kenirek. The ikat-dyeing of the warp and weaving of a kewatek kiwane in Adonara is still subject to taboo, which severely restricted observation.

In spite of these restrictions, the data gathered by the first author show that there is a close resemblance in the process to that found in the study on Lamalera (Barnes 1989:14-45). There are also some interesting differences between Lamalera and Adonara, like the important role in Adonara of warp ikat (mowak) at funerals and the use of morinda-red sarongs. Three main types of kewatek are recognized in Adonara today: the kewatek kiwane, including the most important ceremonial textiles; kewatek grara, or the inalienable cloths of 
the matrilaterally related women bound by the oe kenirek ritual; and kewatek watane, or modern warp-ikat sarongs, which are often woven with machinespun yarn and synthetic dyes.

Clearly, the cultural value of kewatek in Adonara has changed over time. During the famine of the 196os, few people other than elite families could afford to have kewatek woven. During the 1970s agricultural development involving the shift towards planting tree crops for cash restricted the land available for cotton trees. At the same time, wearing modern clothing brought back by labour migrants became fashionable at the expense of wearing kewatek, which became regarded as udik or backward (Somi Kedan 2013).

This article provides an interesting update on the social, cultural, and economic value of kewatek. In the last few decades, the cultural value of ikat sarongs woven in Adonara has started to increase. Young women and men who migrate to Sumba, Java, or beyond in search of a better life ('looking for the larger corn') are presented with one piece of kewatek. They sometimes wear the cloth in public as a token of their Adonara identity, for example at graduation ceremonies. Economic development programmes by regional government and non-government organizations also play an important role in the commoditization of kewatek watane, allowing women to increase their family income. Workshops bring women together from different parts of the island, who now weave with machine-spun yarns and synthetic dyes that have become more widely available. Weavers show much creativity in developing new patterns and colour combinations in weaving kewatek watane and nowin, either for commercial purposes or for private use. ${ }^{30}$ In 2012 the Witihama subdistrict government issued a regulation that restricted the exchange of kewatek at funerary ceremonies to one to three pieces in an effort to control the ostentatious display of cloths by the more affluent elite.

At the time of both Vatter's and Barnes's research on Lamaholot ikat textiles, the older women scolded their daughters for not being interested in making ikat sarongs. It is all the more remarkable that almost a century later, at least on Adonara Island, kewatek or warp-ikat sarongs are still being woven, although the patterns are less complex and homespun cotton and natural dyes are increasingly replaced with machine-spun yarns and chemical dyes. Kewatek kiwane weaving is revitalized, and these traditional textiles seem to enjoy greater social and cultural value as Adonara identity markers, both on the island and in the diaspora. It is hoped that more scientific research will

$30 \quad$ For example, a specific colour combination was invented by Ibu Ina Benga. It was first used by a member of the village choir from Horinara, and has now become the uniform dress of the whole choir. Personal communication, March 2020. 
be undertaken on Adonara kewatek to make an important contribution to our knowledge of Lamaholot textiles, and to show their meaning for the selfidentification of young islanders in the modern world.

\section{Acknowledgements and Biographies}

We thank the two anonymous reviewers for their close reading and valuable comments on an earlier version of this article.

Petronela Somi Kedan SE MSc holds a Master's degree from Wageningen University, the Netherlands, where she graduated in 2013, producing a thesis entitled The changing value and meaning of kewatek in Adonara and Java, Indonesia. Presently Petronela lives in Ende and works at the The Institute for Social Development of Saint Ursula (Sekolah Tinggi Pembangunan Masyarakat Santa Ursula) in Ende, Flores, Indonesia.

Leontine Visser PhD retired as a Professor of Rural Development Sociology from Wageningen University, the Netherlands in 2012. She supervised Petronela's MSc thesis. Her article on textiles from Halmahera, Maluku Utara entitled 'The historical paths of Sahu ceremonial textiles' was published in 2019 in Archipel 98.

\section{References}

Arndt, Paul (1938). 'Demon und Padzi, die feindlichen Brüder des Solor-Archipels', Anthropos 33:1-58.

Badan Pusat Statistik (2011). Kecamatan Witihama dalam angka 2011. Kabupaten Flores Timur: Badan Pusat Statistik.

Badan Pusat Statistik (2012). Sensus Penduduk Kecamatan Witihama. Kecamatan Witihama, Kabupaten Flores Timur: Badan Pusat Statistik.

Barnes, Ruth (1989). The ikat textiles of Lamalera. A study of an Eastern Indonesian weaving tradition. Leiden and New York: Brill.

Barnes, Ruth (1993). 'Change and tradition in Lamaholot textiles. The Ernst Vatter Collection in historical perspective', in: M.-L. Nabholz-Kartaschoff, R. Barnes and D.J. Stuart-Fox (eds), Weaving patterns of life: Indonesian textile symposium 1991, pp. 99-114. Basel: Museum of Ethnography.

Barnes, Ruth (1994). 'East Flores Regency', in: R.W. Hamilton (ed.), Gift of the cotton maiden. Textiles of Flores and the Solor Islands, pp. 170-91. Los Angeles: Fowler Museum of Cultural History, University of California.

Barnes, R.H. (2001). 'Alliance and warfare in an Eastern Indonesian principality. Kédang 
in the last half of the nineteenth century', Bijdragen tot de Taal-, Land- en Volkenkunde 157:271-311.

Barnes, R.H. (2004). 'Keragaman dan persatuan masyarakat di Witihama', Jurnal Antropologi Indonesia, 74:33-47.

Barnes, R.H. (2005). 'Hongi Hinga and its implications: A war of colonial consolidation in the Timor Residency in 1904', Bijdragen tot de Taal-, Land- en Volkenkunde 161-1:139 .

Duggan, G. (2001). Ikats of Savu: Women weaving history in Eastern Indonesia. Bangkok: White Lotus.

Geirnaert, D.C. (1992). The woven land of Laboya. Socio-cosmic ideas and values in West Sumba, Eastern Indonesia. Leiden: CNWS.

Hamilton, R.W. (1994). 'Textile technology', in: R.W. Hamilton (ed.), Gift of the cotton maiden. Textiles of Flores and the Solor Islands, pp. 59-77. Los Angeles: Fowler Museum of Cultural History, University of California.

Hoskins, J. (1998). Biographical objects. How things tell the stories of people's lives. London and New York: Routledge.

Niessen, S. (1985). Motifs of life in Toba Batak texts and textiles. Alblasserdam: Kanters.

Somi Kedan, P. (2013). The changing value and meaning of kewatek in Adonara Island and East Java. https://library.wur.nl/WebQuery/theses?q=Somi+Kedan+2O13 (accessed 25-1-2019). MSc thesis, Wageningen University, Netherlands.

Vatter, E. (1932). Ata Kiwan: unbekannte Bergvölker in Tropischen Holland; ein Reisebericht. Leipzig: Bibliographisches Institut.

Vatter, E. (1984 [1932]). Ata Kiwan. Ende: Percetakan Arnoldus. [The Indonesian translation only covers the western part of the expedition.]

Weiner, A.B. (1992). Inalienable possessions. The paradox of keeping-while-giving. Berkeley: University of California Press.

Wellfelt, E. (2014). The secrets of Alorese 'silk' yarn: Kolon susu, triangle trade and underwater women in Eastern Indonesia. https://digitalcommons.unl.edu/tsasonf (accessed 13-1-2019). 